\title{
DEVELOPMENT OF NASA TECHNICAL STANDARDS PROGRAM RELATIVE TO ENHACING ENGINEERING CAPABILITIES
}

\author{
Paul S. Gill ${ }^{1}$ and William W. Vaughan ${ }^{2}$ \\ ${ }^{1}$ NASA Technical Standards Program Office, NASA Marshall Space Flight Center, Huntsville, AL 35812 \\ 256-544-2557, paul.gill@msfc.nasa.gov \\ ${ }^{2}$ University of Alabama in Huntsville, Huntsville, AL 35899
}

\begin{abstract}
The enhancement of engineering capabilities is an important aspect of any organization; especially those engaged in aerospace development activities. Technical Standards are one of the key elements of this endeavor. The NASA Technical Standards Program was formed in 1997 in response to the NASA Administrator's directive to develop an Agencywide Technical Standards Program. The Program 's principal objective involved the converting Center-unique technical standards into Agency wide standards and the adoption/endorsement of non-Government technical standards in lieu of government standards. In the process of these actions, the potential for further enhancement of the Agency's engineering capabilities was noted relative to value of being able to access Agencywide the necessary full-text technical standards, standards update notifications, and integration of lessons learned with technical standards, all available to the user from one Website. This was accomplished and is now being enhanced based on feedbacks from the Agency's engineering staff and supporting contractors. This paper addresses the development experiences with the NASA Technical Standards Program and the enhancement of the Agency's engineering capabilities provided by the Program's products. Metrics are provided on significant aspects of the Program
\end{abstract}

\section{NASA TECHNICAL STANDARDS PROGRAM INITIATIVE}

The NASA Technical Standards Program (http://standards.nasa.gov) was formally established in 1997 as an Agencywide effort by direction of the Administrator. It has the following principal elements:

***Increase NASA Use of Voluntary Consensus (non-Government) Technical Standards. ***Selective Development of NASA-Unique Technical Standards.

***Develop and Promote the Use of an Integrated Technical Standards Initiative (Full-

Text Standards Access, Standards Update Notifications, and Lessons

Learned-Standards Integration).

***Exploit the Potential of Web-based Standardization Information.

Technical Standards are an integral part of all engineering development efforts, especially those in the aerospace industry. Designers and engineers should be among the most aggressive supporters of a strong Technical Standards program. Standardization activities establish engineering and technical applications for processes and practices and, in doing so, enhance engineering capabilities. Thus, they enable designers to not dissipate their energies on the costly exercise of "reinventing the wheel."

Like their colleagues in the private sector, NASA has also depended upon the active application of Technical Standards developed by the Agency through its various Centers, as well as Department of Defense (DoD) Technical Standards (i.e., Military Standards, 
Specifications, Handbooks, etc.) and those produced by non-Government Standards Developing Organizations (SDOs). Since the late 1990s, NASA has been engaged in a major Agencywide effort to review the Technical Standards produced by its Centers and, to the degree practical, utilizes a systematic consensus driven approach resulting in the adoption (endorsement) of relevant non-Government Technical Standards to replace its Center-developed Technical Standards. The adopted Technical Standards are known as "NASA Preferred Technical Standards." In areas where adoption is not practical, efforts have been made to consolidate similar Center-developed Technical Standards and produce replacement Technical Standards endorsed for Agencywide use. This substantial endeavor was undertaken and subsequently increased in response to the Office of Management and Budget (OMB) Circular A-119 "Federal Participation in the Development and Use of Voluntary Consensus Standards and in Conformity Assessment Activities", February 1998.

In the process of responding to the directives contained in OMB Circular A-119, it was discovered that the Agency's Programs/Projects and engineering staff were in need of a consolidated Web-based Technical Standards database accessible from a single source with engineering oversight. The information requested included full-text Technical Standards products issued by the Agency and its Centers, Department of Defense, and non-Government SDOs. In addition, requirements for timely information on changes in Technical Standards products were also noted.

The need for improving the process to address customer needs for efficiency in the acquisition of Technical Standards products is one of the Strategic Initiatives identified in the American National Standards Institute's (ANSI) National Standards Strategy For The United States (http://web.ansi.org/public/nss.html). In particular the document identified the need for cost-effective mechanisms such as update notification and electronic accessibility of Technical Standards products from SDOs. The NASA Integrated Technical Standards Initiative, while not developed to solve this problem for the United States, is a step toward solving the problem of Technical Standards distribution and, thus, enhancement of engineering capabilities within one Government Agency that has potential for use by others.

After several reviews and pilot exercises, additional dialog with several Program/Project Managers and engineering groups, the concept of a "One Stop Shop" web-based NASA Integrated Technical Standards Initiative began to materialize. The two main advantages that became immediately apparent were: (1) The Agency's engineering capabilities will be considerably enhanced by providing NASA's technical and engineering communities with immediate on-line access to Technical Standards products and (2) Significant cost savings could be realized by having one unified Agencywide Full-Text Technical Standards System versus having fourteen or more individual groups within the Agency acquiring Technical Standard products independent of each other. Standards updates and lessons learned were also indicated as important information to enhance the engineering usage of Technical Standards. Thus, the unique "NASA Integrated Technical Standards Initiative" was born. The Initiative consists of the following three Systems: 
(1) Agencywide Full-Text Technical Standards System

(2) Standards Update Notification System

(3) Lessons Learned/Best Practices/Application Notes-Standards Integration System.

The primary goal of the NASA Technical Standards Initiative is to develop a suite of collaborative tools to: (1) Augment NASA's use and support the adoption of nonGovernment Voluntary Consensus Standards by making them available from a single source, (2) Provide notifications on changes, updates, and revisions to existing Technical Standards, (3) Provide information on engineering lessons learned, best practices, and experiences related to specific Technical Standards products, and (4) Enhance the engineering capabilities of the Agency

\section{ENHANCING ENGINEERING CAPABILITES AND TECHNICAL STANDARDS}

The motivation for the development of Technical Standards varies considerably. However, one most often sees economic issues as the principal motivation. Applications to regulatory matters are another strong motivation. International competitiveness, commodity confidence, safeguards for health, safety, and environment, reducing risks, facilitating commercial communications, technology transfer and among the other principal motivations note for Technical Standards. However, enhancing engineering capabilities is not often seen in the list of motivations for the development and promotion of Technical Standards. Perhaps this is assumed as a given reason and, thus, not necessary to mention.

Enhancing engineering capabilities is the key to the nation's future in the rapidly growing globalization of industry. For the United States to remain competitive and maintain its technical leadership in the world, enhancing the nation's engineering capabilities is very critical to success. This is necessary for the education of future engineers and the improvement of current engineers. Technical Standards provide a major opportunity to achieve the goal of enhancing engineering capabilities, especially when a process such as the NAS Integrated Technical Standards Initiative is implemented. This Initiative consists of the following Systems.

\section{Agencywide Full-Text Technical Standards System}

This System provides access to full-text on-line Technical Standards products and distribution for NASA use. Technical Standards products are currently available from 108 Standards Developing Organizations, including those of NASA, DoD, and other Agencies. For those Technical Standards not available electronically, a hardcopy is made available to the requester within 24-36 hours. A pilot version of the System was implemented in 2000 with favorable feedback leading to the Agencywide implementation of the System in June 2001. Currently their are over 5,500 registered NASA and supporting contractor users within the <nasa.gov $>$ Domain. 


\section{Standards Update Notification System}

This System provides NASA and its supporting contractors with notice of updates (revisions, cancellations, superseded documents, etc.) to Technical Standards products that they have identified for use on their Programs/Projects or research activities. This information is provided so that update notices of technical changes on a Technical Standards product can be evaluated by the Program/Project Manager for impact on the Program/Project requirements. This System is linked with the Agencywide Full-Text Technical Standards System to provide the latest full-text versions of the Technical Standards on demand. Documents identified by the user and accepted for update notification are screened relative to adoption as NASA Preferred Technical Standards. The System was made available Agencywide in October 2001. There are now over 4,000 standards documents registered by users for update notifications.

\section{Lessons Learned/Best Practices/Application Notes-Standards Integration System}

This System provides links to Lessons Learned/Best Practices/Application Notes that have applicability to use of individual Technical Standards products. As of this date, 225

Lessons Learned from NASA's Lessons Learned Information System have been linked to 125 NASA Preferred Technical Standards listed on the NASA Technical Standards Program Website. Also, 140 Application Notes have been related to 95 NASA Preferred Technical Standards. Identifying other Application Notes and Lessons Learned to link with specific NASA Preferred Technical Standards is a continuing effort. These Lessons Learned, Best Practices, and Application Notes will also be of great benefit in identifying non-Government Voluntary Consensus Standards to adopt/endorse for NASA use. Over 150 links to engineering Lessons Learned/Best Practices Websites and documents have been identified and provided on the Program's Website. These additional sites are not only from NASA Facilities, but other Government and non-Government bodies. They provide users with technical information on a variety of aerospace engineering related lessons learned topics. The NASA Technical Standards Program Office prepared a paper entitled "Lessons Learned and Technical Standards-A Logical Marriage" that was published in the November 2001 issue of ASTM Standardization News and subsequently reprinted in DOD Standardization Journal and The Standards Forum of DOE. It focuses on the importance of the relationship between Lessons Learned and Technical Standards, and, thus, the enhancement of engineering capabilities.

An example is provided of what a NASA staff member or supporting contractor user of the NASA Technical Standards Program Website has available. It is shown on the figure of the document Summary Page. When the user calls up a NASA Preferred Technical Standard under the Agencywide Full-Text Technical Standards System, a document Summary Page will appear that provides summary information on the Technical Standard. When available, information on applicable Application Notes, Lessons Learned and Best Practices is provided along with link to the Standards Update Notification System to receive notice of any revisions, updates, cancellations, etc. on a given Technical Standard. 


\section{Concluding Remarks}

The figure provides a view of the NASA Technical Standards Program Website Homepage. On it the NASA ACCESS and PUBLIC ACCESS menu items are noted along with some allied menu topics. The contents of the Website were formulated and organized with the objective of enhancing engineering capabilities throughout the Agency and with its supporting contractors. To date, the usage of the three Systems in the NASA Technical Standard Initiative has been outstanding in terms of user interests an value to their work on NASA Programs/Projects and research activities. The metrics associated with each of these Systems continue to show increased usage. This is due to the ready availability of the NASA Technical Standards Program products and related information on-line, and reinforces the validity of the "One Stop Shop" concept.

Enhancing engineering capabilities is one of the most important values of Technical Standards, especially when coupled with allied information. This coupling is the key to enhancing engineering capabilities, whether within NASA or otherwise. Such is the thrust of the NASA Technical Standards Program. This has been achieved by the development and implementation of the NASA' Integrated Technical Standard Initiative.

This thrust by NASA to enhance engineering capabilities throughout the Agency is being reinforced and expanded based on feedbacks from the engineering staff of NASA and its supporting contactors. The integration of Technical Standards, update notifications, and lessons learned information is one step toward the goal of significantly enhancing engineering capabilities necessary to meet the future demands for timely, productive, and reliable space systems and contributing to improved cost.

\section{Bibliography}

Anon., "National Standards Strategy for the United States." American National Standards Institute, Washington, D.C. August 2000

Anon., "MilSpec Reform: An Interview With George E. Saunders, Defense Standardization Program Office." ASTM Standardization News, Vol. 29, No. 1, November 2001. pp 15-19.

Anon., "Japanese Industrial Standards Committee-Standardization Strategy (Summary)." ASTM Standardization News, Vol. 29, No. 11, December 2001. pp 33-34

Gill, P. S., Barcia, D., and Vaughan, W. W. "Lessons Learned and Technical Standards: A Logical Marriage for Future Space Systems Design." $53^{\text {rd }}$ International Astronautical Congress, The World Space Congress-2002, Paper \# IAC-02-U.3.04, Houston, TX, October 10-19, 2002.

Gill, P. S., Vaughan, W. W., and Garcia, D., "Lessons Learned and Technical Standards: A Logical Marriage." ASTM Standardization News, Vol. 29. No. 11, November 2001. pp $2-27$. 
Kelly, G. E., "Including Standards in the Education of Future Engineers." Journal of Standards Engineering, Vol. 53, No. 1, January/February, 2001. pp 1, 3-5.

Tanski, P., "Role of Standards and Standardization in the Commercial Space Launch Industry." Journal of Standards Engineering, Vol. 52, No. 2, March/April 2001. pp 1012.

Prepared For Presentation at:

Space Technology and Applications International Forum (STAIF-2003)

Conference on Human Space Exploration

Albuquerque, New Mexico

February 2-6, 2003 


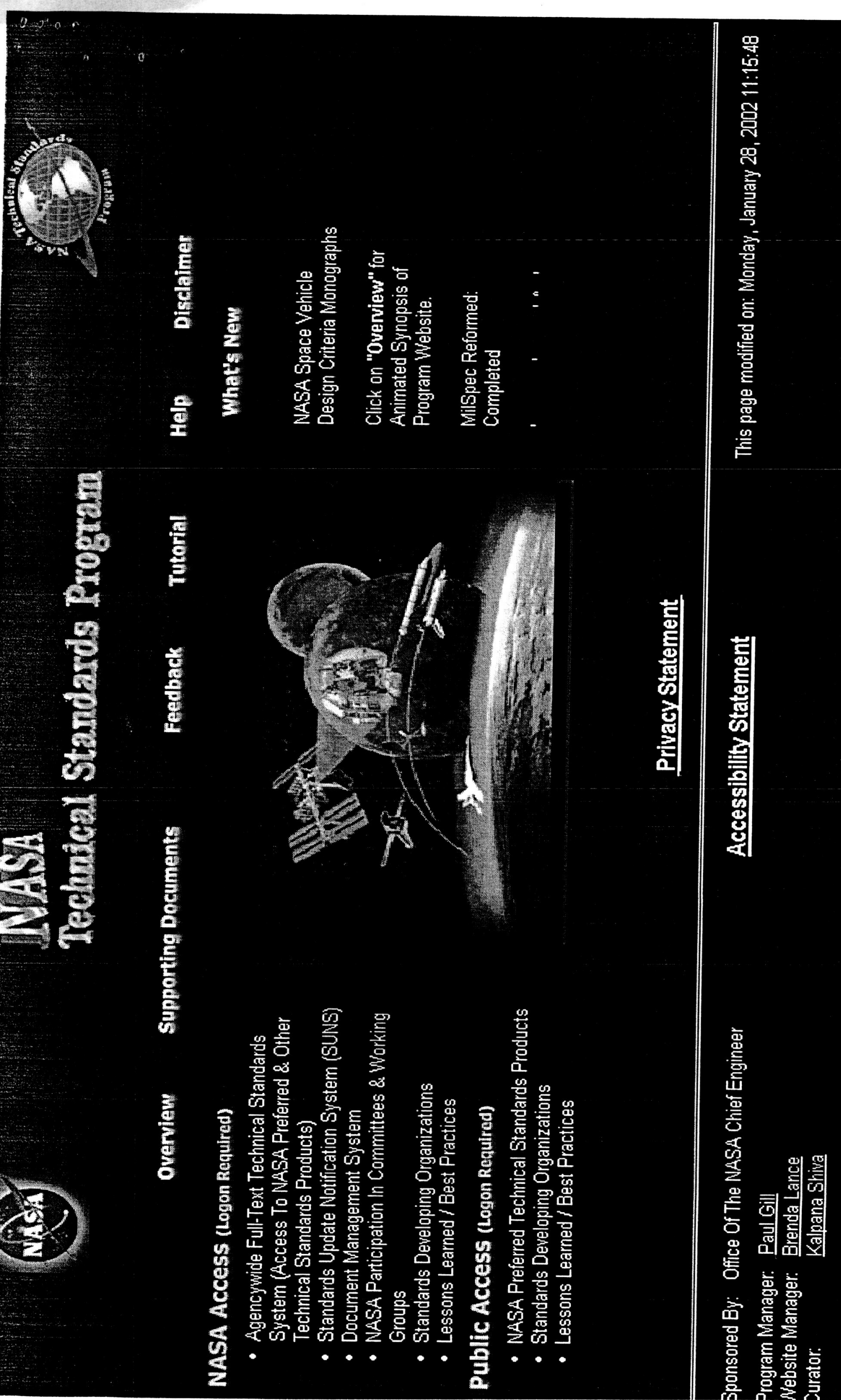

